\title{
Halobacillus mangrovi sp. nov., a moderately halophilic bacterium isolated from the black mangrove Avicennia germinans
}

Correspondence Rafael Montalvo-Rodríguez titomontal@yahoo.com

\author{
Nelís Soto-Ramírez, ${ }^{1}$ Cristina Sánchez-Porro, ${ }^{2}$ Soniris Rosas-Padilla, \\ Karinna Almodóvar, ${ }^{1}$ Gina Jiménez, ${ }^{1}$ Marlene Machado-Rodríguez, ${ }^{1}$ \\ Magaly Zapata, ${ }^{1}$ Antonio Ventosa ${ }^{2}$ and Rafael Montalvo-Rodríguez ${ }^{1}$ \\ ${ }^{1}$ Biology Department, Box 9012, University of Puerto Rico, Mayagüez, Puerto Rico 00681 \\ ${ }^{2}$ Department of Microbiology and Parasitology, Faculty of Pharmacy, University of Sevilla, \\ 41012 Sevilla, Spain
}

The genus Halobacillus was first described by Spring et al. (1996) in order to accommodate Sporosarcina halophila (Claus et al., 1983) together with two novel species, namely Halobacillus litoralis and Halobacillus trueperi. At the time of writing, the genus comprises nine recognized species, Halobacillus halophilus (type species of the genus), Halobacillus litoralis, Halobacillus trueperi (Spring et al., 1996), Halobacillus salinus (Yoon et al., 2003), Halobacillus karajensis (Amoozegar et al., 2003), Halobacillus locisalis (Yoon et al., 2004), Halobacillus aidingensis, Halobacillus dabanensis (Liu et al., 2005) and Halobacillus yeomjeoni (Yoon et al., 2005). Besides the ability to produce ellipsoidal or spherical endospores at the central or subterminal position, one of the main features of the genus Halobacillus is the cell-wall peptidoglycan type based on L-Orn-D-Asp, in contrast to the meso-diaminopimelic

The GenBank/EMBL/DDBJ accession number for the 16S rRNA gene sequence of strain $\mathrm{MS}^{\top} \mathrm{O}^{\top}$ is $\mathrm{DQ888316}$. acid or L-lysine type cell-wall peptidoglycan found in related genera (Shida et al., 1997; Yoon et al., 2003). There have been no previous reports of members of the genus Halobacillus associated with mangroves that thrive in saline habitats.

Avicennia germinans (black mangrove) is a type of mangrove that has developed mechanisms to tolerate high salt concentrations in unstable substrates, to obtain oxygen from almost anoxic sediments and to reproduce under harsh environmental conditions. One of these mechanisms is the ability to secrete salt crystals on to the surface of its leaves when the salt concentration is in excess of that normally present in the vascular system (Lugo \& Snedaker, 1975). In the present study, we determined the taxonomic position of bacterial strain $\mathrm{MS}^{\mathrm{T}}{ }^{\mathrm{T}}$, which was isolated from the surface of leaves of the black mangrove during a microbial diversity study. On the basis of the results presented, we show that strain $\mathrm{MS}^{\mathrm{T}} 0^{\mathrm{T}}$ represents a novel species of the genus Halobacillus. 
Strain $\mathrm{MS}^{\mathrm{T}}$ was isolated from the surface of black mangrove leaves. For isolation, leaves from A. germinans trees growing near the solar salterns of Cabo Rojo, Puerto Rico, were obtained and pressed against agar plates containing Sehgal-Gibbons medium [SG; $15 \% \mathrm{NaCl}, 2 \%$ $\mathrm{MgSO}_{4} \cdot 7 \mathrm{H}_{2} \mathrm{O}, 0.2 \% \mathrm{KCl}, 0.3 \%$ trisodium citrate, $0.002 \%$ $\mathrm{FeCl}_{2}, 0.75 \%$ Casamino acids, $1 \%$ yeast extract $(\mathrm{w} / \mathrm{v})$, $\mathrm{pH}$ 7.5-7.8] (Sehgal \& Gibbons, 1960). This procedure allowed the transfer of the micro-organisms present in the salt crystals and on the surface of the leaves to the growth medium. Plates were incubated at $30{ }^{\circ} \mathrm{C}$. After 3 days incubation, the leaves were removed aseptically and colonies were then selected and purified by the quadrant streak plate method. Pure cultures were transferred to SG medium for further biochemical and molecular analysis.

Cell morphology was examined by use of the Nomarsky technique and scanning electron microscopy on cells at the exponential phase of growth under optimal conditions. Electron microscopy procedures were performed as described by Díaz-Muñoz \& Montalvo-Rodríguez (2005). Gram staining was investigated by using both heat-fixed smears and smears fixed in 5\% acetic acid (Dussault, 1955). Macroscopic properties were documented by using the classical characterization of colony appearance. Optimal conditions for growth were determined by growing strain $\mathrm{MS}^{\mathrm{T}}{ }^{\mathrm{T}}$ in SG broth supplemented with 0 , $5,10,15,20,25$ and $30 \%(\mathrm{w} / \mathrm{v}) \mathrm{NaCl}$ and at temperatures of $10,15,20,25,30,33,35,40$ and $50{ }^{\circ} \mathrm{C}$. The $\mathrm{pH}$ range for growth was tested in SG medium with $10 \% \mathrm{NaCl}$ adjusted to $\mathrm{pH}$ values of $4.0,5.0,6.0,7.0,8.0,9.0$ and 10.0 with the addition of the appropriate buffering ability to each medium as described by Montalvo-Rodríguez et al. (2000). Cells were cultivated in SG medium with constant agitation (150 r.p.m.) and growth was monitored by measuring absorbance at $600 \mathrm{~nm}$. Growth curves used to test the conditions mentioned above were generated from duplicate experiments and the mean generation time was calculated.

Cells of strain $\mathrm{MS} 0^{\mathrm{T}}$ were Gram-positive, spore-forming, short rods. Cells were 1.0-2.0 $\mu \mathrm{m}$ long and 0.5-1.0 $\mu \mathrm{m}$ wide at the exponential phase of growth in SG medium with $10 \% \mathrm{NaCl}$ at $30{ }^{\circ} \mathrm{C}$. Cells were motile. On SG medium with $10 \% \mathrm{NaCl}$, colonies were cream-brown, entire, circular, convex and elevated. Strain $\mathrm{MS}^{\mathrm{T}}{ }^{\mathrm{T}}$ grew at $\mathrm{NaCl}$ concentrations in the range $5-20 \%(\mathrm{w} / \mathrm{v})$ in SG medium. It was not able to grow at $\mathrm{NaCl}$ concentrations above $20 \%(\mathrm{w} / \mathrm{v})$. Growth was observed at temperatures of $10-50{ }^{\circ} \mathrm{C}$ and at $\mathrm{pH}$ values of $6.0-9.0$. Optimal growth conditions in SG medium were at $10 \%(\mathrm{w} / \mathrm{v}) \mathrm{NaCl}, 33-$ $35{ }^{\circ} \mathrm{C}$ and $\mathrm{pH}$ 7.0. This combination of conditions produced the shortest generation time $(0.52 \mathrm{~h})$.

All biochemical tests were carried out at $10 \% \mathrm{NaCl}$ and $30{ }^{\circ} \mathrm{C}$ unless stated otherwise. Catalase activity was determined by adding a $1 \%(\mathrm{w} / \mathrm{v}) \mathrm{H}_{2} \mathrm{O}_{2}$ solution to colonies on SG agar medium. The oxidase test was performed by using the Dry Slide (Difco) biochemical test
(Montalvo-Rodríguez et al., 1998). Hydrolysis of starch, Tween 80 and aesculin were determined as described by Cowan \& Steel (1965) with the addition of basal salts [10\% $\mathrm{NaCl}, 2 \% \mathrm{MgSO}_{4} \cdot 7 \mathrm{H}_{2} \mathrm{O}$ and $\left.0.2 \% \mathrm{KCl}(\mathrm{w} / \mathrm{v})\right]$ to the medium. Hydrolysis of gelatin and production of urease were determined according to Cowan \& Steel (1965). Citrate utilization was determined on Simmons' citrate medium (SIM; Simmons, 1926) supplemented with basal salts. Acid production from carbohydrates was determined by using phenol red base supplemented with $0.7 \%$ of the carbohydrate and basal salts. Motility was determined by using SIM medium, supplemented with basal salts. Growth under anaerobic conditions was determined by incubating strain $\mathrm{MS} 10^{\mathrm{T}}$ in an anaerobic chamber in SG medium with $10 \%(\mathrm{w} / \mathrm{v}) \mathrm{NaCl}$. Tests for enzyme activities (qualitative) were carried out by using the API ID32E system (bioMérieux) inoculated according to the manufacturer's instructions, with the inoculated fluid at $10 \% \mathrm{NaCl}$ and incubation at $35{ }^{\circ} \mathrm{C}$. Nutritional characteristics were determined by using Koser medium (Koser, 1923) as modified by Ventosa et al. (1982), which contains the basal salts described above, together with (w/v) $0.1 \% \mathrm{KNO}_{3}$, $0.1 \% \quad\left(\mathrm{NH}_{4}\right)_{2} \mathrm{HPO}_{4}$ and $0.05 \% \quad \mathrm{KH}_{2} \mathrm{PO}_{4}$. The filtersterilized substrate was added to this medium at a final concentration of $0.1 \%(\mathrm{w} / \mathrm{v})$, with the exception of carbohydrates, which were used at a final concentration of $0.2 \%(\mathrm{w} / \mathrm{v})$. Antibiotic susceptibility was determined according to the conventional Kirby-Bauer method (Bauer et al., 1966). The phenotypic characteristics of strain $\mathrm{MS}_{10}{ }^{\mathrm{T}}$ are summarized and compared with those of the type strains of related Halobacillus species in Table 1 and also in the species description below.

For characterization and sequencing of the 16S rRNA gene, strain $\mathrm{MS} 10^{\mathrm{T}}$ was grown in SG medium at $10 \%(\mathrm{w} / \mathrm{v}) \mathrm{NaCl}$ and incubated at $30^{\circ} \mathrm{C}$. Genomic DNA was extracted from cells in lysis buffer followed by phenol/chloroform extraction and ethanol precipitation. This DNA was used as template for subsequent PCR amplification. Reaction conditions and amplification protocols were performed as described by Hezayen et al. (2002). The resulting amplicon was purified by using the MinElute PCR purification kit according to the manufacturer's instructions (Qiagen). Purified PCR products were sent to a DNA sequencing facility (Macrogen, Republic of Korea). Distance analysis of the resulting DNA sequences was performed by using the PHYLIP program (version 3.63) (Felsenstein, 1993). A multiple-sequence alignment was made by using the CLUSTAL $\mathrm{W}$ program with $16 \mathrm{~S}$ rRNA gene sequences of closely related organisms (as identified by BLAST analysis) (Maidak et al., 1996). 16S rRNA gene sequence similarity values were calculated by pairwise comparison of the sequences within the alignment. The program SEQBOOT was used to generate 100 bootstrapped data sets. Distance matrices were calculated with DNADIST. One hundred trees were inferred by using the NEIGHBOR software package. Any bias introduced by the order of sequence addition was minimized by randomizing the input order. The CONSENSE 
Table 1. Characteristics that distinguish strain $M S 10^{\top}$ from the type strains of related species of the genus Halobacillus

Taxa: 1, strain MS10 ${ }^{\mathrm{T}}$; 2, H. dabanensis (data from Liu et al., 2005); 3, H. aidingensis (Liu et al., 2005); 4, H. karajensis (Amoozegar et al., 2003); 5, H. halophilus (Spring et al., 1996); 6, H. litoralis (Spring et al., 1996). +, Positive; -, negative.

\begin{tabular}{|c|c|c|c|c|c|c|}
\hline Characteristic & 1 & 2 & 3 & 4 & 5 & 6 \\
\hline Cell morphology & Rods & Rods & Clubs & Rods & Cocci or ovals & Rods \\
\hline Motility & + & + & + & - & + & + \\
\hline \multicolumn{7}{|l|}{ Acid production from: } \\
\hline D-Fructose & - & + & + & + & - & + \\
\hline D-Glucose & - & + & + & + & - & + \\
\hline Maltose & - & + & + & + & - & + \\
\hline Sucrose & - & + & + & - & - & + \\
\hline D-Xylose & - & + & - & - & - & + \\
\hline \multicolumn{7}{|l|}{ Hydrolysis of: } \\
\hline Aesculin & - & - & - & + & - & - \\
\hline Casein & + & + & + & + & + & - \\
\hline
\end{tabular}

program was used to determine the most frequent branching order. The final tree was drawn by using TreeView (Page, 1996).

In silico analysis by using the BLAST program (National Center for Biotechnology) of the almost complete 16S rRNA gene sequence $(1460 \mathrm{bp})$ of strain $\mathrm{MS}^{\mathrm{T}} \mathrm{T}^{\mathrm{T}}$ revealed that this strain was related to members of the genus Halobacillus and showed highest sequence similarity to $H$. dabanensis JCM $12772^{\mathrm{T}}(99.2 \%)$. Strain $\mathrm{MS}^{\mathrm{T}}{ }^{\mathrm{T}}$ showed levels of 16S rRNA gene sequence similarity of 97.9, 98.6, 98.5, 98.2, 98.7 and $98.8 \%$ to $H$. aidingensis JCM $12771^{\mathrm{T}}$, H. yeomjeoni DSM $17110^{\mathrm{T}}$, H. karajensis DSM $14948^{\mathrm{T}}, H$. locisalis DSM $16468^{\mathrm{T}}, H$. trueperi CCM $4593^{\mathrm{T}}$ and $H$. litoralis DSM $10405^{\mathrm{T}}$, respectively. Phylogenetic analysis according to the neighbour-joining algorithm revealed that strain $\mathrm{MS}^{\mathrm{T}}{ }^{\mathrm{T}}$ belonged to the cluster encompassing members of the genus Halobacillus (Fig. 1). Similar results were obtained for strain $\mathrm{MS}_{10}{ }^{\mathrm{T}}$ when the maximumparsimony and maximum-likelihood algorithms were used.

Fatty acids were analysed by using the MIDI system (Microbial Identification System). Cells were cultured on marine agar supplemented with $8.1 \% \mathrm{NaCl}$ for $24-48 \mathrm{~h}$ at $35{ }^{\circ} \mathrm{C}$ and the cellular fatty acids were analysed by GC at the Belgian Co-ordinated Collections of Micro-organisms, Laboratory of Microbiology (BCCM/LMG), Gent, Belgium (Miller, 1982; Kämpfer \& Kroppenstedt, 1996). Cell-wall composition analysis was carried out by the Identification Service of the DSMZ (Braunschweig, Germany) by using the methods described by Schleifer \& Kandler (1972). The analysis of respiratory quinones was carried out by the Identification Service of the DSMZ (Braunschweig, Germany). The predominant fatty acids of strain $\mathrm{MS}_{10}{ }^{\mathrm{T}}$ were iso- $\mathrm{C}_{16: 0}$, anteiso- $\mathrm{C}_{15: 0}$, iso- $\mathrm{C}_{14: 0}$ and iso- $\mathrm{C}_{15: 0}$
(Table 2). The cell-wall peptidoglycan was of L-Orn-DAsp type and the main isoprenoid quinone was menaquinone 7 (MK-7).

The $\mathrm{G}+\mathrm{C}$ content of the genomic DNA of strain $\mathrm{MS}_{10}^{\mathrm{T}}$ was determined from the mid-point value $\left(T_{\mathrm{m}}\right)$ of the thermal denaturation profile (Marmur \& Doty, 1962) by using the equation of Owen \& Hill (1979), as previously described in detail by Ventosa et al. (1999). The DNA $\mathrm{G}+\mathrm{C}$ content of strain $\mathrm{MS}^{\mathrm{T}}{ }^{\mathrm{T}}$ was $45.7 \mathrm{~mol} \%$. This value is close to those reported for recognized species of the genus Halobacillus (Spring et al., 1996; Amoozegar et al., 2003; Yoon et al., 2003, 2004, 2005; Liu et al., 2005).

DNA-DNA hybridization studies were performed according to the competition procedure of the membrane method (Johnson, 1994), as described in detail by Mormile et al. (1999). The hybridization temperature was $48.7^{\circ} \mathrm{C}$, which was within the limit of validity for the filter method (De Ley \& Tijtgat, 1970) and the percentage hybridization was calculated according to Johnson (1994). The experiments were carried out in triplicate. The level of DNA-DNA hybridization between strain $\mathrm{MS}^{\mathrm{T}}$ and $H$. dabanensis JCM $12772^{\mathrm{T}}$ was $29 \%$. Strain MS10 ${ }^{\mathrm{T}}$ showed levels of DNA-DNA hybridization to $H$. locisalis DSM $16468^{\mathrm{T}}, H$. trueperi CCM $4593^{\mathrm{T}}, H$. aidingensis JCM $12771^{\mathrm{T}}, H$. litoralis DSM $10405^{\mathrm{T}}, H$. karajensis DSM $14948^{\mathrm{T}}$, H. yeomjeoni DSM $17110^{\mathrm{T}}$ and $H$. salinus JMC $11546^{\mathrm{T}}$ of $44,32,49,36,51,44$ and $36 \%$, respectively. These values are sufficiently low to classify strain $\mathrm{MS}^{\mathrm{T}} 0^{\mathrm{T}}$ as representing a genotypically distinct species within the genus Halobacillus (Wayne et al., 1987).

Notable phenotypic differences were found between strain $\mathrm{MS}_{10}{ }^{\mathrm{T}}$ and $H$. dabanensis JCM $12772^{\mathrm{T}}$, its closest phylogenetic relative. Strain $\mathrm{MS}^{\mathrm{T}} 0^{\mathrm{T}}$ was unable to produce 


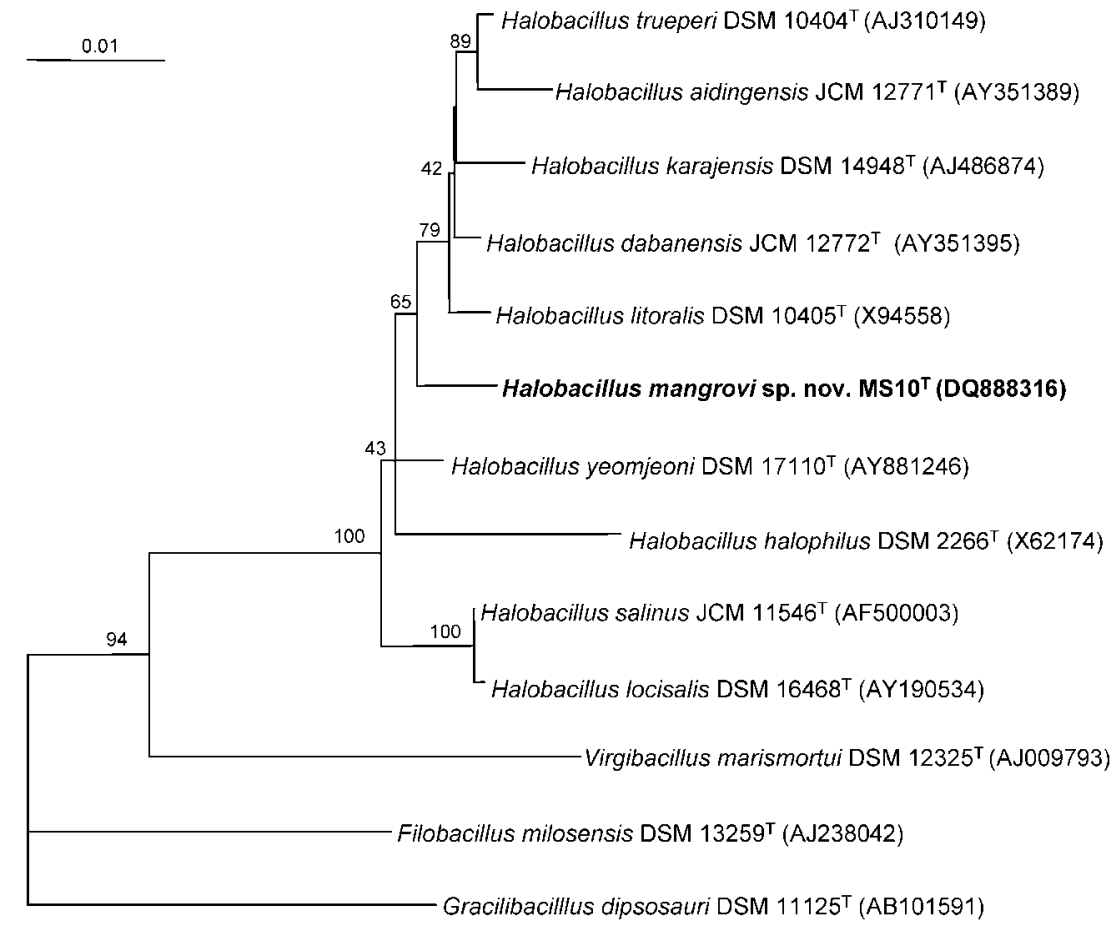

Fig. 1. Neighbour-joining distance tree using the 16S rRNA gene sequences of strain $M S 10^{\top}$ and closely related species. Bootstrap values higher than $40 \%$ are shown. Gracilibacilllus dipsosauri DSM $11125^{\top}$ was used as the outgroup. Bar, 1 substitution per $100 \mathrm{nt}$. acid from any of the carbohydrates tested, in direct contrast to the results for $H$. dabanensis. Strain $\mathrm{MS}_{10}{ }^{\mathrm{T}}$ was able to hydrolyse gelatin, whereas $H$. dabanensis could not. The biochemical properties of strain $\mathrm{MS}^{\mathrm{T}} 0^{\mathrm{T}}$ were very similar to those of $H$. halophilus, although there were differences in cell shape and colony pigmentation (Table 1). In addition, differences in fatty acid content together with $16 \mathrm{~S}$ rRNA gene sequence dissimilarities suggest that strain

Table 2. Cellular fatty acid content of strain $M S 10^{\top}$ and closely related Halobacillus species

Taxa: 1 , strain $\mathrm{MS}^{\mathrm{T}}$; 2, H. dabanensis; 3, H. aidingensis; 4, H. litoralis; 5, H. trueperi; 6, H. salinus; 7, H. locisalis; 8, H. halophilus. 13, Data from the present study; 4-8, data from Yoon et al. (2003). All strains were grown on marine agar supplemented with $8.1 \% \mathrm{NaCl}$ (final $\mathrm{NaCl}$ concentration of $10 \%$ ) according to Yoon et al. (2003). Values are percentages of total fatty acids. ND, not detected.

\begin{tabular}{|c|c|c|c|c|c|c|c|c|}
\hline Fatty acid & 1 & 2 & 3 & 4 & 5 & 6 & 7 & 8 \\
\hline$C_{15: 0}$ & ND & $\mathrm{ND}$ & $\mathrm{ND}$ & 1.1 & ND & 1.6 & 1.1 & 1.5 \\
\hline $\mathrm{C}_{16: 0}$ & 1.5 & 2.3 & 1.4 & 0.6 & 0.9 & 1.0 & 0.9 & 0.9 \\
\hline anteiso- $\mathrm{C}_{13: 0}$ & $\mathrm{ND}$ & $\mathrm{ND}$ & ND & 0.4 & ND & $\mathrm{ND}$ & 0.5 & 0.4 \\
\hline anteiso- $\mathrm{C}_{15: 0}$ & 22.8 & 49.9 & 21.7 & 57.0 & 25.3 & 31.7 & 42.0 & 47.3 \\
\hline anteiso- $\mathrm{C}_{17: 0}$ & 4.5 & 19.3 & 6.5 & 8.2 & 6.5 & 6.2 & 13.0 & 11.9 \\
\hline iso- $\mathrm{C}_{14: 0}$ & 17.1 & 1.9 & 19.8 & 6.4 & 21.7 & 9.4 & 11.2 & 12.2 \\
\hline iso- $\mathrm{C}_{15: 0}$ & 14.8 & 7.5 & 10.8 & 15.8 & 7.7 & 26.3 & 8.4 & 7.5 \\
\hline iso- $\mathrm{C}_{16: 0}$ & 32.2 & 14.2 & 31.7 & 5.4 & 31.5 & 15.7 & 15.9 & 15.2 \\
\hline iso- $\mathrm{C}_{17: 0}$ & 4.4 & 4.4 & 5.2 & 1.5 & 2.1 & 4.2 & 1.4 & 1.2 \\
\hline $\mathrm{C}_{16: 1} \omega 7 c$ alcohol & 2.6 & 0.5 & 3.0 & 2.0 & 3.8 & 4.0 & 5.7 & 1.8 \\
\hline iso- $\mathrm{C}_{17: 1} \omega 10 c$ & $\mathrm{ND}$ & $\mathrm{ND}$ & ND & 0.2 & $\mathrm{ND}$ & $\mathrm{ND}$ & $\mathrm{ND}$ & $\mathrm{ND}$ \\
\hline
\end{tabular}

$\mathrm{MS}^{\mathrm{T}}{ }^{\mathrm{T}}$ can be considered to represent a species distinct from $H$. halophilus.

Overall, the phenotypic, genotypic and phylogenetic results presented in this study demonstrate that strain $\mathrm{MS}_{10}^{\mathrm{T}}$ represents a novel species of the genus Halobacillus, for which the name Halobacillus mangrovi sp. nov. is proposed.

\section{Description of Halobacillus mangrovi sp. nov.}

Halobacillus mangrovi (man.gro'vi. N.L. n. mangrovum mangrove; N.L. gen. n. mangrovi of a mangrove).

Gram-positive, spore-forming, short rods, 1-2 $\mu \mathrm{m}$ long and $0.5-1 \mu \mathrm{m}$ wide. Cells are motile. Colonies are creambrown, entire, circular, convex and elevated. Moderately halophilic, growing at $\mathrm{NaCl}$ concentrations in the range of $5-20 \%(\mathrm{w} / \mathrm{v})$ with optimum growth at $10 \%(\mathrm{w} / \mathrm{v}) \mathrm{NaCl}$. Growth occurs at temperatures of $10-50{ }^{\circ} \mathrm{C}$ (optimal 33$35{ }^{\circ} \mathrm{C}$ ) and $\mathrm{pH}$ 6.0-9.0 (optimal pH 7.0). Strictly aerobic. Catalase and oxidase are produced. Negative for aesculin, indole, $\mathrm{H}_{2} \mathrm{~S}$ production, methyl red, Voges-Proskauer reaction, urease and Tween 80 . Gelatin, casein and starch are hydrolysed. Nitrate is not reduced. No acid production from glucose, sucrose, maltose, mannitol, xylose, fructose, mannose, D-melibiose, L-rhamnose, D-sorbitol, D-galactose, inositol, sorbitol, adonitol, L-arabitol, D-arabitol, L-arabinose, palatinose, trehalose, cellobiose, galacturonic acid, potassium 5-ketogluconate or sodium pyruvate. Starch, Dglucose, D-sorbitol and succinate are used as carbon and energy sources. Negative for arginine dihydrolase, ornithine decarboxylase and lipase (C14). Positive for $\beta$ galactosidase, $\alpha$-glucosidase, $\alpha$-galactosidase and $\alpha$-mannosidase. Negative for lysine decarboxylase, $\beta$-glucosidase, 
$\beta$-glucuronidase, $N$-acetyl- $\beta$-glucosaminidase and L-aspartic acid arylamidase. Resistant to ( $\mu \mathrm{g}$ per disc) polymixin (300 U), neomycin (30), streptomycin (10) and sulfamethoxazole/trimethoprim (23.75/1.25). Shows intermediate resistance to ( $\mu \mathrm{g}$ per disc) erythromycin (15), nalidixic acid (30) and tetracycline (30). Sensitive to ( $\mu$ g per disc) kanamycin (30), rifampicin (5), bacitracin (10 U), vancomycin (30), novobiocin (30), cephalothin (30), penicillin (10 U) and chloramphenicol (30). The cell-wall peptidoglycan is of L-Orn-D-Asp type. The major respiratory quinone is $\mathrm{MK}-7$. The major fatty acids are iso- $\mathrm{C}_{16: 0}$, anteiso- $\mathrm{C}_{15: 0}$, iso- $\mathrm{C}_{14: 0}$ and iso- $\mathrm{C}_{15: 0}$. The DNA G+C content is $45.7 \mathrm{~mol} \%$.

The type strain, $\mathrm{MS}_{10}^{\mathrm{T}}\left(=\mathrm{CECT} 7206^{\mathrm{T}}=\mathrm{CCM} 7397^{\mathrm{T}}\right)$, was isolated from the leaf surface of Avicennia germinans (black mangrove).

\section{Acknowledgements}

We should like to thank Donato Seguí, José Almodóvar and members of R. M.-R.'s laboratory for technical assistance, and also Dr Jean P. Euzéby for help with etymology. This study was supported by grants from the Quality of Life and Management of Living Resources Programme of the European Commission (Project 'Multigenome Access Technology for Industrial Catalysts', QLK3-CT-2002-01972), Spanish Ministerio de Educación y Ciencia (BMC2003-01344 and BIO2006-06927), from the Junta de Andalucia, by the Dean of Arts and Sciences Seed Money Program at the University of Puerto RicoMayagüez Campus, and Puerto Rico Math and Science Partnership (PR-MSP) sponsored by the National Science Foundation (NSF), Grant no. HER-031455 F.

\section{References}

Amoozegar, M. A., Malekzadeh, F., Malik, K. A., Schumann, P. \& Sproer, C. (2003). Halobacillus karajensis sp. nov., a novel moderate halophile. Int J Syst Evol Microbiol 53, 1059-1063.

Bauer, A. W., Kirby, W. M. M., Sherris, J. C. \& Turck, M. (1966). Antibiotic susceptibility testing by a standarized single disk method. Am J Clin Pathol 45, 493-496.

Claus, D., Fahmy, F., Rolf, H. J. \& Tosunoglu, N. (1983). Sporosarcina halophila sp. nov., an obligate, slightly halophilic bacterium from salt marsh soils. Syst Appl Microbiol 4, 496-506.

Cowan, S. T. \& Steel, K. J. (1965). Manual for the Identification of Medical Bacteria. London: Cambridge University Press.

De Ley, J. \& Tijtgat, R. (1970). Evaluation of membrane filter methods for DNA-DNA hybridization. Antonie van Leeuwenhoek 36, 461-474.

Díaz-Muñoz, G. \& Montalvo-Rodríguez, R. (2005). Halophilic black yeast Hortaea werneckii in the Cabo Rojo solar salterns: its first record for this extreme environment in Puerto Rico. Caribb J Sci 41, 360-365.

Dussault, H. P. (1955). An improved technique for staining redhalophilic bacteria. J Bacteriol 70, 484-485.

Felsenstein, J. (1993). PHYLIP (phylogeny inference package), version 3.6. Distributed by the author. Department of Genome Sciences, University of Washington, Seattle, USA.

Hezayen, F. F., Tindall, B. J., Steinbuchel, A. \& Rehm, B. H. A. (2002). Characterization of a novel halophilic archaeon, Halobiforma haloterrestris gen. nov., sp. nov., and transfer of Natronobacterium nitratireducens to Halobiforma nitratireducens comb. nov. Int J Syst Evol Microbiol 52, 2271-2280.

Johnson, J. L. (1994). Similarity analysis of DNAs. In Methods for General and Molecular Bacteriology, pp. 655-681. Edited by P. Gerhardt, R. G. E. Murray, W. A. Wood \& N. R. Krieg. Washington, DC: American Society for Microbiology.

Kämpfer, P. \& Kroppenstedt, R. M. (1996). Numerical analysis of fatty acid patterns of coryneform bacteria and related taxa. Can J Microbiol 42, 989-1005.

Koser, S. A. (1923). Utilization of the salts of organic acids by the colon-aerogenes group. J Bacteriol 8, 493-520.

Liu, W. Y., Zeng, J., Wang, L., Dou, Y. T. \& Yang, S. S. (2005). Halobacillus dabanensis sp. nov. and Halobacillus aidingensis sp. nov., isolated from salt lakes in Xinjiang, China. Int J Syst Evol Microbiol 55, 1991-1996.

Lugo, A. E. \& Snedaker, S. C. (1975). Properties of a mangrove forest in southern Florida. In Actas, International Symposium on Biological Management of Mangroves, pp. 170-212. Edited by G. Walsh, S. C. Snedaker \& H. Teas. Gainesville: University of Florida.

Maidak, B. L., Olsen, G. J., Larsen, N., Overbeek, R., McCaughey, M. J. \& Woese, C. R. (1996). The Ribosomal Database Project (RDP). Nucleic Acids Res 24, 82-85.

Marmur, J. \& Doty, P. (1962). Determination of the base composition of deoxyribonucleic acid from its thermal denaturation temperature. J Mol Biol 5, 109-118.

Miller, L. T. (1982). Single derivation method for routine analysis of bacterial whole-cell fatty acid methyl esters, including hydroxyl acids. J Clin Microbiol 16, 584-586.

Montalvo-Rodríguez, R., Vreeland, R. H., Oren, A., Kessel, M., Betancourt, C. \& López-Garriga, J. (1998). Halogeometricum borinquense gen. nov., sp. nov., a novel halophilic archaeon from Puerto Rico. Int J Syst Bacteriol 48, 1305-1312.

Montalvo-Rodríguez, R., López-Garriga, J., Vreeland, R. H., Oren, A., Ventosa, A. \& Kamekura, M. (2000). Haloterrigena thermotolerans sp. nov., a halophilic archaeon from Puerto Rico. Int J Syst Evol Microbiol 50, 1065-1071.

Mormile, M. R., Romine, M. F., Garcia, M. T., Ventosa, A., Bailey, T. J. \& Peyton, B. M. (1999). Halomonas campisalis sp. nov., a denitrifying, moderately haloalkaliphilic bacterium. Syst Appl Microbiol 22, 551-558.

Owen, R. J. \& Hill, L. R. (1979). The estimation of base compositions, base pairing and genome sizes of bacterial deoxyribonucleic acids. In Identification Methods for Microbiologists (Society for Applied Bacteriology Technical Series no. 14), 2nd edn, pp. 277-296. Edited by F. A. Skinner \& D. W. Lovelock. London: Academic Press.

Page, R. D. M. (1996). TreeView: an application to display phylogenetic trees on personal computers. Comput Appl Biosci 12, 357-358.

Schleifer, K. H. \& Kandler, O. (1972). Peptidoglycan types of bacterial cell walls and their taxonomic implications. Bacteriol Rev 36, 407-477.

Sehgal, S. N. \& Gibbons, N. E. (1960). Effect of metal ions on the growth of Halobacterium cutirubrum. Can J Microbiol 6, 165-169.

Shida, O., Takagi, H., Kadowaki, K., Nakamura, L. K. \& Komagata, K. (1997). Transfer of Bacillus alginolyticus, Bacillus chondroitinus, Bacillus curdlanolyticus, Bacillus glucanolyticus, Bacillus kobensis, and Bacillus thiaminolyticus to the genus Paenibacillus and emended description of the genus Paenibacillus. Int J Syst Bacteriol 47, 289-298.

Simmons, J. S. (1926). A culture medium for differentiating organisms of typhoid-colon aerogenes groups and for isolation of certain fungi. J Infect Dis 39, 209-217.

Spring, S., Ludwig, W., Marquez, M. C., Ventosa, A. \& Schleifer, K. H. (1996). Halobacillus gen. nov., with descriptions of Halobacillus 
litoralis sp. nov. and Halobacillus trueperi sp. nov., and transfer of Sporosarcina halophila to Halobacillus halophilus comb. nov. Int J Syst Bacteriol 46, 492-495.

Ventosa, A., Quesada, E., Rodríguez-Valera, F., Ruiz-Berraquero, F. \& Ramos-Cormenzana, A. (1982). Numerical taxonomy of moderately halophilic Gram-negative rods. J Gen Microbiol 128, 1959-1968.

Ventosa, A., Gutierrez, M. C., Kamekura, M. \& Dyall-Smith, M. L. (1999). Proposal to transfer Halococcus turkmenicus, Halobacterium trapanicum JCM 9743 and strain GSL-11 to Haloterrigena turkmenica gen. nov., comb. nov. Int J Syst Bacteriol 49, 131-136.

Wayne, L. G., Brenner, D. J., Colwell, R. R., Grimont, P. A. D., Kandler, O., Krichevsky, M. I., Moore, L. H., Moore, W. E. C., Murray, R. G. E. \& other authors (1987). International Committee on Systematic Bacteriology. Report of the ad hoc committee on reconciliation of approaches to bacterial systematics. Int J Syst Bacteriol 37, 463-464.

Yoon, J. H., Kang, K. H. \& Park, Y. H. (2003). Halobacillus salinus sp. nov., isolated from a salt lake on the coast of the East Sea in Korea. Int J Syst Evol Microbiol 53, 687-693.

Yoon, J. H., Kang, K. H., Oh, T. K. \& Park, Y. H. (2004). Halobacillus locisalis sp. nov., a halophilic bacterium isolated from a marine solar saltern of the Yellow Sea in Korea. Extremophiles 8, 23-28.

Yoon, J. H., Kang, S. J., Lee, C. H., Oh, H. W. \& Oh, T. K. (2005). Halobacillus yeomjeoni sp. nov., isolated from a marine solar saltern in Korea. Int J Syst Evol Microbiol 55, 2413-2417. 